experienced no difficulties while working on the project. Despite the contradiction in general attitude towards remote learning and unusual learning environment, the students demonstrated more self-discipline and initiative and successfully managed to coordinate project work, divide responsibilities and exploit technology, which resulted in a high-quality project presentation. Overall the learners managed to perform effectively and benefit from the remote learning. The results of this work may be used for further analysis and improvement of online and distance education routine.

\title{
References:
}

1. T. Dudley-Evans and M. J. St John (2012).Developments in English for Specific Purposes. A Multi-disciplinary approach. Cambridge University Press.

2. J. W. Thomas, A Review of Research on Project-Based Learning, 2000. Retrieved September 10, 2009 from www.bobpearlman.org/ BestPractices/PBL_Research.pdf

3. J. A. Coleman, Project-based learning, transferable skills, information technology and video, Language Learning Journal, 5, 35-37, 1992

4. S.A. McLeod (2020, March 20). Maslow's hierarchy of needs. Simply Psychology. https://www.simplypsychology.org/maslow.html

DOI https://doi.org/10.30525/978-9934-26-110-7-85

\section{«PEER FEEDBACK» AS AN ALTERNATIVE ASSESSMENT METHOD IN EFL TEACHING IN SENIOR CLASSES}

\author{
Slyvka M. I. \\ Candidate of Philological Sciences, \\ Associate Professor of English Philology Department \\ Uzhhorod National University \\ Slyvka N. T. \\ Senior Teacher of Department of Foreign Languages \\ Uzhhorod National University \\ Uzhhorod, Ukraine
}

The quality of education is one of the important factors determining the success of a graduate of an educational institution. Despite some developments, in practice, when evaluating learning outcomes, needs, motivations and interests of the student are not always taken into account. Peer 
feedback of students is declared in assessing learning outcomes; however, it is almost never used in practice. This occurs for a number of reasons, among which there is a lack of demand on the part of society for the student to be included in assessment, as well as socio-economic reasons rather than pedagogical ones. Obviously, taking into account personal characteristics self-evaluation and peer feedback, along with an external assessment by a teacher or expert, will largely satisfy the educational, cognitive needs and interests of the student, will contribute to the effective implementation of the tasks of the state standard of education. The above-mentioned facts predetermine the relevance of the research.

The aim of the article is to analyze the process of evaluating learning outcomes with the help of peer-feedback in EFL teaching in senior school.

Feedback is a crucial element in language teaching and learning. It can promote minimal or deep learning. J. Hattie and H. Timperely argue that feedback is «information provided by an agent regarding some aspects of one's task performance» [1, p. 81]. S. Narciss also outlines feedback as «all post-response information that is provided to a learner to inform the learner on his or her actual state of learning or performance» [3, p. 127]. What is clear from these definitions is that feedback is devised to provide an understanding of performance by means of offering guidance on the knowledge that they possess. Peer feedback implies students' feedback or grading to other students on the quality of learning tasks performance.

A variety of forms for assessment in EFL classes are suggested in the literature. Some teachers prefer using reflective diaries, blogs or journals as they boost critical reflection on an individual level. If the teacher wants students' essays to be assessed, it is better to use feedback sheets which focus students on main points for the assessment: what was the best or the worst, the most difficult or easy. Considering this form, teachers should be aware that criteria for self- and teacher's assessment are the same. In such way, it would be easier to compare your impression and to justify your grade in case if students do not agree [2, p. 63].

In terms of peer feedback, teachers should bear in mind that it is a rather time and resource consuming procedure and the effectiveness and validity may only come with practice. Such activities as feedback discussions, note exchange and sharing the solution of the problems are considered as preparing activities for the peer feedback implementation. Another hindrance encountered by teachers is the creation of trustful environment in a class.

If students have never experienced peer feedback, it is recommended to start with simple activities such as feedback catchwords, PMI and spoof assessment [4, p. 70]. Feedback Catchwords are usually short and simple peer feedback statements. For example: Today you did well on.....; The point you 
should improve is...; Next time try to.... PMI stands for plus, minus and interesting. It is a useful tool to teach students to define strong and weak point of a peer's work. Students get a written sample or a peer's work and mark it with these letters PMI where it is necessary. Spoof assessment is used for identifying mistakes and correcting them. A teacher gives students pieces of writing with previously made mistakes. Students have to find them and correct if they can with the following discussion why it is wrong.

When students learn these activities and skills, they may be suggested more complicated activities as graphing progress and snowballing. These activities require systematic application as they develop more complicated skills. Graphing progress implies progress graphs charting with the data provided by a teacher from class achievements for a period of time. Students can share their graphs and discuss their progress, give helpful advice how their classmates can achieve success or improve.

$\mathrm{Yu}$. Lavrysh describes snowballing as the activity involving the whole group or class as it develops collaborative and team skills. Students work in small groups and are given some tasks to perform, which they initially worked on individually at home. In a class, students compare answers of all members of a group, choose the best one and try to explain why they chose that solution [2, p. 64].

At advanced level of acquisition of peer feedback skills, students can perform peer editing, testing learning, peer essays and feedback strategies. Testing learning is described as the creation of students' own tests, quizzes or questionnaires with a marking scale on a covered topic or learned issue. The tests are presented during a class and suggested to other students. The advantage of the activity is that students not only test their mates' knowledge but are able to suggest feedback on how to improve the knowledge or where to search for the information. The peer editing or feedback giving is a completely student-centred activity. Students are asked not to grade the works but to provide a feedback on the peers' performance as reviewers [2, p. 65]. So, students get an opportunity to respond to the assessment. Peer essays are pair activity in which students help each other with ideas for a writing task performing. At first, students work individually, then they are grouped into pares for a discussion. After that, students can whether write together or finish the essay individually depending on the learning goal.

Peer feedback is considered as an important dominant tool in enhancing the process of learning English writing. It also is viewed as students' social activity. Some researchers interpret peer feedback as an ineffective technique for improving students' performance and prefer teacher feedback to peer feedback. However, some researchers have claimed that peer feedback 
in EFL classes is useful because of the cognitive and social advantages of peer feedback.

Peer feedback encourages students to analyse their mistakes, to establish new learning goals, to improve learning methods, and to delineate own strengths and areas which need improvement. The main purpose of this process is to provide the opportunity for students to identify what work is considered to be good or bad rather than simply generate grades. Peer feedback fosters profound learning as students can compare new knowledge with previously learnt and discover new levels of the subject understanding.

Peer feedback implies students' feedback or grading to other students on the quality of learning tasks performance. Peer feedback boosts team or collaborative working skills, negotiating and judgment skills and adequate critique abilities. It represents a powerful instrument for students to be in the role of «assessor» and to take responsibility for the assessment process and its results. It motivates students to manifest the excellence in learning of a subject as they have to assess the understanding of the subject rather than just knowledge of facts. In addition, it is always better to study from other's mistakes as well as from their success.

Peer feedback give the possibility to develop such ability as «objective» evaluation that is crucial for a fair critique. Peer feedback makes EFL lessons more interactive and involves feedback discussions. In some cases, students even get better and more complete and relevant formative feedback from their peers than from their teachers.

As the modern educational approaches require reducing the teacher's involvement into the EFL learning process, peer feedback evaluation helps to overcome the predominance of teachers' power and allows students to feel equality with a teacher as a partner in a learning process which promotes collaborative learning.

However, the implementation of such type of assessment may arose certain defficulties. Since students are inexperienced assessors, the question of validity and reliability may arise. Morover, peer feedback may involve inaccuracy in assessment and, thus, may cause misunderstandings and conflicts. Consequently, there is a discussion whether the peer-generated grades should be used as formative or summative assessment.

Further study of the problem may concern the use of peer feedback for developing writing skills in learning English as a foreign language.

\section{References:}

1. Hattie J. The power of feedback. Review of Educational Research, 1(77). 2007. P. 81-112. 
2. Lavrysh Yu. Peer and Self-Assessment at Esp Classes: Case Study. Advanced Education, 2016, Issue 6. P. 60-68.

3. Narciss S. Feedback strategies for interactive learning tasks. \& M. P. Driscoll (Eds.). Handbook of research on educational communications and technology. Mahwah. NJ: Lawrence Erlbaum, 2008. P. 125-144.

4. Stognieva O. Implementing peer assessment in a Russian university ESP classroom. Journal of Language and Education, 4(1). 2015. P. 63-73.

DOI https://doi.org/10.30525/978-9934-26-110-7-86

\title{
НОВІТНІ КОМП'ЮТЕРНІ ТЕХНОЛОГІЇ В НАВЧАННI IНОЗЕМНИМ МОВАМ
}

\author{
Шапошникова О. Л. \\ старший викладач кафедри міжкультурної комунікаиії \\ та іноземної мови \\ Національний технічний університет \\ «Харківський політехнічний інститут» \\ м. Харків, Украӥна
}

Навчання іноземним мовам з використанням новітніх комп'ютерних технологій - риса сьогодення. Комп'ютерні технології в навчанні англійській, німецькій, французькій мовам широко впроваджені в практичну навчальну роботу НТУ «ХПІ». Дистанційне навчання всіх освітніх дисциплін все більше поширюється в освітньому процесі, тим більше, що його підштовхнув карантин пандемії COVID-19 в 2020 році. [1, с. 1] Сьогодні настав час розробки цілісної концепції роботи 3 будь-якою дисципліною для подальшого росту ефективності дистанційних технологій навчання. Дистанційне навчання іноземним мовам займає не останнє місце серед них.

Тому, в вищих навчальних закладах України, зокрема в Національному технічному університеті «Харківський політехнічний інститут», дистанційному навчанню всіх освітніх дисциплін, i іноземних мов в тому числі, приділяється особлива увага. Пріоритетом став пошук новацій в розробці освітніх технологій і методичних підходів до проведення занять в умовах пандемії, коли заперечується скупчення учнів в аудиторіях. При цьому, як і завжди, викладачі і науковці шукають 